\title{
Konsep Diri Akademik Dengan Pengambilan Keputusan Karier Pada Siswa SMP
}

\author{
Agung Santoso Pribadi ${ }^{1}$, Erwin Erlangga ${ }^{2}$, Maria Yuliana Wangge ${ }^{3}$ \\ 1,2,3Fakultas Psikologi, Universitas Semarang \\ e-mail:1Agung84@usm.ac.id
}

\begin{abstract}
Article History:
Received

8 April 2021

Review

7 Mei 2021

Revised

18 Mei 2021

Accepted

19 Mei 2021

Published

23 Juni 2021

Reviewer A:

Mulawarman
\end{abstract}

Abstrak. Penelitian ini bertujuan untuk menguji secara empiris hubungan antara Konsep Diri dengan Pengambilan keputusan Karier pada Siswa SMP. Subjek Penelitian ini berjumlah 157 siswa Kelas IX SMP Mardisiswa 2 Semarang. Metode Pengumpulan data dalam penelitian ini menggunakan Skala yang terdiri dari Skala Konsep Diri dan Skala Pengambilan Keputusan Karier. Analisis Data yang digunakan dengan menggunakan teknik Korelasi Product Moment. Hipotesis yang diajukan dalam penelitian ini adalah adanya hubungan positif Antara Konsep Diri dengan Pengambilan keputusan karier. Hasil Penelitian ini menunjukkan bahwa rxy $=0,869$ $(\mathrm{p}=0,000) \mathrm{p}<0,05$, maka hipotesis dalam penelitian ini diterima. Kata kunci: Konsep Diri akademik, Pengambilan keputusan Karier

\section{Pendahuluan}

Undang-undang sistem pendidikan nasional Nomor 20 Tahun 2003 menyatakan bahwa pendidikan adalah usaha sadar dan terencana untuk mewujudkan suasana belajar dan proses pembelajaran agar peserta didik secara aktif mengembangkan potensi dirinya untuk memiliki kekuatan spiritual keagamaan, pengendalian diri, kepribadian, kecerdasan, akhlak mulia serta keterampilan yang diperlukan masyarakat, bangsa dan negara (Muhibin, 2004: 23).

Berdasarkan Undang-Undang tentang pendidikan dapat kita lihat bahwa salah satu tujuan pendidikan yaitu untuk membekali siswa agar memiliki keterampilan yang kelak dapat mendukung pemenuhan persyaratan dan tuntutan pekerjaan. Keterampilan yang memadai merupakan persyaratan materiil seseorang untuk dapat bekerja. Pendidikan sendiri merupakan persyaratan formil seseorang untuk dapat membuktikan bahwa dirinya telah memiliki keterampilan untuk bekerja sesuai keterampilan yang didapatkan dalam proses pendidikan. Sebagai contoh, individu dengan ijazah SMK Pariwisata dianggap telah mempunyai keterampilan dan kemampuan untuk bekerja pada perusahaan yang menjalankan usaha sektor pariwisata. 
Dalam rangka mewujudkan tujuan pendidikan di atas, maka diperlukan adanya proses bimbingan. Bimbingan diselenggarakan untuk membantu mengoptimalkan perkembangan siswa, salah satunya pengambilan keputusan karir. Kemampuan pengambilan keputusan karir siswa dapat diupayakan melalui program bimbingan karir. Bimbingan karir adalah suatu proses bantuan, layanan dan pendekatan terhadap individu (siswa/remaja), agar individu yang bersangkutan dapat mengenal dirinya, memahami dirinya, dan mengenal dunia kerja, merencanakan masa depannya, dengan bentuk kehidupan yang diharapkannya, untuk menentukan pilihannya, dan mengambil suatu keputusan bahwa keputusannya adalah yang paling tepat sesuai dengan keadaan dirinya dihubungkan dengan persyaratan-persyaratan dan tuntutan pekerjaan/karir yang dipilihnya (Gani, 1996: 11).

Mengenai pengambilan keputusan karir, Sukardi (1993:63) menyatakan bahwa pengambilan keputusan karir merupakan suatu proses dimana seseorang mengadakan suatu seleksi terhadap beberapa pilihan dalam rencana masa depan. Penjelasan lebih lanjut dikemukakan oleh Munandir (1996: 191), yang menyatakan bahwa keputusan karir yang dimaksud adalah keputusan yang diambil secara arif dan penuh telaah serta penuh pertimbangan. Pengambilan keputusan seperti ini mutlak dilakukan demi keberhasilan dalam hidupnya kelak dengan karir yang dipilihnya itu. Dalam pengambilan keputusan karir, siswa-siswa SMP berada pada tahap kritis (remaja akhir) antara dua pilihan yang sangat menentukan. Pertama, untuk memilih melanjutkan keperguruan tinggi atau berhubungan dengan dunia kerja. Kedua untuk mencapai kematangan dalam pemilihan karir untuk menghadapi kedua pilihan tersebut (Achmad Juntika Nurihsan \& Akur Sudianto, 2005: 2). Para siswa Sekolah Menengah Atas (SMA) dalam menentukan pilihan karirnya memerlukan beberapa pertimbangan sebelum mengambil keputusan. Pengambilan keputusan karir yang ditandai dengan adanya penetapan pilihan karir adalah persoalan penting bagi siswa Sekolah Menengah Pertama (SMP), karena akan menentukan arah karirnya pada masa yang akan datang.

Proses perkembangan karir siswa Sekolah Menengah Pertama (SMP) mengalami perubahan dalam pemilihan karir karena beralih dari fase tentatif yang berada pada tahap transisi menuju fase realistik serta dengan adanya masalah-masalah yang berasal dari dalam diri, luar diri, dan keduanya. Kondisi sosial, ekonomi, budaya yang mengalami perubahan kearah perkembangan minat, sikap, harapan dan kemampuan berpengaruh dalam proses pengambilan keputusan karir yang merupakan bagian dari proses perkembangan karir dalam perencanaan hidup (life planning). Berdasarkan uraian 
tersebut, kematangan memilih karir meliputi: (1) pemahaman dan kemampuan membuat rencana yang tepat, (2) sikap konsisten terhadap tanggung jawab, dan (3) kesadaran terhadap segala faktor internal yang harus dipertimbangkan dalam membuat keputusan karir (Winkel, 1997: 575). Dari uraian di atas dapat kita lihat bahwa salah satu faktor yang dapat mempengaruhi keberhasilan proses perkembangan karir tersebut adalah tingkat kematangan pemahaman diri.

Pemahaman diri merupakan perbuatan atau cara memahami dan menguasai pikiran serta perasaan diri. Dalam merencanakan karir, pemahaman diri merupakan suatu hal yang sangat penting. Dengan adanya pemahaman diri, maka seseorang akan lebih mampu merencanakan karir di masa depan. Pemahaman diri mendorong individu untuk mengetahui kelebihan, kekurangan dirinya, hambatan, dan cara mengatasi masalah. Pengembangan kreativitas dalam berkarir memerlukan pemahaman tentang nilai-nilai, minat, bakat, IQ, dan kepribadian, sehingga siswa akan memperoleh gambaran dan cenderung akan memberikan arah dalam kehidupan seseorang untuk merencanakan masa depan. Masa-masa SMP merupakan masa belajar yang sangat penting bagi perkembangan individu seseorang menentukan karir. Yang dimaksud dengan belajar di sini tidak hanya mencakup keterampilan belajar praktis, melainkan juga memperoleh perspektif yang lebih luas tentang belajar di seluruh area pengembangan manusia.

Dari hasil wawancara pada tanggal 12 Oktober 2019 sebagai guru BK, diperoleh informasi bahwa terdapat beberapa siswa mengalami kesulitan dalam mengambil keputusan karir. Siswa merasa bingung untuk melanjutkan ke SMA atau SMK. Bimbingan dan Konseling karir disampaikan oleh Guru BK dengan menggunakan metode ceramah ditiap-tiap kelas pada saat jam pelajaran BK yang berdurasi 45 menit, sehingga siswa kurang informasi dan belum memiliki gambaran tentang karir.

Upaya setiap siswa untuk mencapai tujuan dalam karir yang diinginkan, kadangkala menemui hambatan di tengah jalan. Kenyataan tersebut terjadi akibat dari berbagai kendala dan faktor yang dapat merintangi usaha seseorang untuk mencapai suatu tujuan yang diinginkan seperti pengalaman, ekonomi, lingkungan yang berasal dari diri sendiri maupun dari luar dirinya sendiri. Permasalahan karir siswa terdiri dari dua faktor, yaitu faktor internal dan eksternal. Faktor internal yaitu kepribadian diri siswa yang cenderung tertutup, belum fokus dengan keterampilan yang dimiliki yaitu sudah mengambil jurusan sesuai dengan keterampilan yang dimiliki, namun ia merasa mampu dalam keterampilan lain dan ingin mencoba keterampilan tersebut, tidak percaya diri, dan adanya minat lain yaitu ketika siswa sudah mempunyai minat terhadap bidang 
tertentu akan tetapi karena banyaknya pilihan siswa berminat terhadap bidang yang lain. Faktor eksternal yaitu ekonomi keluarga menyebabkan pilihan karir siswa jadi terhambat yaitu siswa kebanyakan tidak bisa menentukan pilihan karirnya dengan memasuki pendidikan yang lebih tinggi, akan tetapi langsung memasuki dunia kerja karena kondisi ekonomi orang tua yang kurang mampu. Selain itu orang tua juga cenderung memaksakan kehendaknya agar anak memilih pekerjaan, jenjang pendidikan dan bidang pendidikan yang diinginkan oleh orang tua seperti orang tua menginginkan anaknya setelah lulus melanjutkan ke perguruan tinggi dan mengambil jurusan kedokteran, tetapi kemampuan anaknya bukan di bidang eksakta, ia lebih mampu di bidang sosial. Hal ini menyebabkan anak tidak dapat memililih karir sesuai dengan minat dan potensi yang dimiliki.

Hurlock (2001: 42) menyatakan bahwa remaja yang lebih tua, berusaha mendekati masalah karir dengan sikap yang lebih praktis dan lebih realistis dibandingkan dengan ketika ia masih kanak-kanak. Namun dari sebagian siswa masih ada yang kebingungan dengan perkembangan karirnya, padahal mereka sama-sama sudah mendapat informasi karir di sekolah. Mereka merasa bingung dengan pilihan apakah terus melanjutkan sekolah, ke perguruan tinggi atau bekerja. Crites (2007: 31) menemukan bahwa 30\% peserta didik merasa bingung semasa berada di sekolah sebagai akibat dari minimnya pengetahuan mereka tentang karir masa depan.

Perasaan kebingungan ini diakui oleh Erikson (Salomone dan Mangicaro, 1991: 52) yang menyatakan bahwa peserta didik di Sekolah Menengah Atas saat ini berada pada tahap kebingungan peran yang berbahaya (the danger of this stage is role confusion). Selain itu perbedaan dalam aspirasi karir, di antara siswa-siswa lanjutan atas ternyata terdapat perbedaan subtansial dalam kebutuhan perkembangan dan kematangan karirnya. Banyak faktor yang menyebabkan perbedaan-perbedaan ini. Faktor-faktor tersebut antara lain tingkat bantuan orang tua, latar belakang jenis kelamin rasial dan konsep diri, perkembangan dan kesehatan fisik.

Fenomena di atas menggambarkan bahwa untuk mencapai tingkat kematangan dalam suatu tahap tertentu atau mencapai tingkat kematangan yang komprehensif, siswa yang bersangkutan berulang kali melakukan pertimbangan dan penilaian kembali sesuai potensi diri, nilai-nilai, serta pengaruh lingkungan yang senantiasa berubah-ubah (Munandir, 1996: 90). Agar siswa dapat melakukan pertimbangan dan penilaian secara tepat, maka diperlukan layanan bimbingan karir di sekolah, solusi untuk mengatasi masalah-masalah karir dan strategi dalam rangka mematangkan kemampuan memilih, 
merencanakan karir, dan mengembangkan karir siswa.

Bimbingan karir merupakan salah satu jenis bimbingan yang berusaha membantu siswa dalam memecahkan masalah karir (pekerjaan), untuk memperoleh penyesuaian diri yang sebaik-baiknya, kegiatan layanan yang diberikan kepada siswa dengan tujuan agar siswa memperoleh pemahaman diri, nilai, dunia kerja dan pada akhirnya mampu menentukan pada pilihan karir dan menyusun perencanaan kerja dengan baik dan berhasil (Utoyo, 2016: 2). Dengan mengetahui dirinya sendiri, kemampuannya dan arah kebutuhan- kebutuhannya, individu akan berada dalam posisi untuk mempertimbangkan alternatif-alternatif yang akan datang, dan mengerti tujuantujuan pendidikan, pekerjaan dan kehidupannya (Utoyo, 2016: 26). Dengan pemahaman yang baik terhadap potensi diri, sikap, nilai, serta kepribadian yang dicocokkan dengan keadaan lingkungan pekerjaan dan perencanaan karir yang tepat siswa dapat memilih karir berdasarkan kemampuan yang dimiliki melalui proses belajar. Untuk merencanakan kehidupan karir lebih baik, diperlukan suatu bimbingan yang memberikan bekal cukup kepada siswa. Dalam mengatasi dan mewujudkan hal tersebut diperlukan layanan berupa layanan bimbingan karir.

Layanan bimbingan karir sangat diperlukan dalam usaha memberikan arahan dan petunjuk kepada siswa dalam menentukan karir di masa mendatang diperlukan strategi membantu mengembangkan karir siswa. Tanpa petunjuk dan arahan, siswa tidak akan mendapatkan gambaran tentang masa depannya yang disesuaikan dengan bakat, potensi dan kemampuan yang dimiliki, sehingga dengan adanya layanan bimbingan karir, diharapkan lulusan Sekolah Menengah Atas (SMA) siap kerja dan memiliki sikap kemandirian yang dapat diandalkan mampu untuk menghadapi persaingan era globalisasi dan tantangan masa depan karir.

Pelaksanaan layanan bimbingan karir dapat terlaksana dengan lancar dan baik apabila didukung oleh konselor dan petugas bimbingan lain dengan membuat program yang tepat, melaksanakan dengan baik, dan mengevaluasi program dan pelaksanaanya. Program bimbingan karir yang baik, berisi metode penyampaian yang tepat, teknik pendekatan, sumber-sumber informasi karir, serta sarana dan prasarana bimbingan karir.

Tujuan-tujuan program bimbingan karir perlu ditetapkan dengan sasaran yang jelas, dan menetapkan kriteria yang dapat diukur dan dapat dipertanggungjawabkan di antaranya perkembangan karir yang termasuk pemberian informasi baik informasi pendidikan, pekerjaan, maupun aspek kehidupan lain yang pada dasarnya 
perkembangan karir tidak hanya membantu siswa dalam mencapai dunia kerja saja, tetapi juga aspek-aspek kehidupan yang lain sesuai dengan tugas-tugas perkembangan siswa (Utoyo, 1997: 4-6).

Berdasarkan fenomena tersebut di atas terlihat bahwa bimbingan karir di Sekolah Menengah Pertama (SMP) sangat penting dalam menciptakan kemandirian siswa dalam memilih karir dan berkarir. Selain itu dapat memberikan gambaran dan harapan yang akan dicapai oleh siswa di masa yang akan datang di dunia karirnya, sehingga diharapkan lulusan Sekolah Menengah Pertama (SMP) memiliki sikap kemandirian yang dapat diandalkan mampu untuk menghadapi persaingan era globalisasi dan tantangan masa depan karir, serta mencetak tenaga terampil untuk mempersiapkan diri dalam memasuki dunia kerja dengan pemenuhan kompetensi di berbagai pengembangan. Dengan kondisi yang demikianlah diperlukan layanan bimbingan karir, permasalahanpermasalahan yang menghambat perkembangan karir siswa.

Berdasarkan uraian di atas, maka penelitian terhadap kemampuan pengambilan keputusan karir siswa sangat penting untuk dilakukan agar dapat mengetahui sejauh mana kemampuan siswa untuk mengambil keputusan karir. Diharapkan dengan penelitian ini setelah mengetahui tingkat kemampuan siswa dalam pengambilan keputusan karir, dapat juga diketahui hambatan dan solusi pemecahannya. Dengan alasan tersebut, peneliti mengambil penelitian tentang "Hubungan Antara Knsep Diri dengan Pengambilan Keputusan Karier pada SIswa SMP, karena di sekolah ini belum pernah diadakan penelitian mengenai kemampuan pengambilan keputusan karir siswa.

\section{Konsep Diri AKademik}

\section{Pengertian Konsep Diri}

Banyak pengertian yang diberikan oleh para ahli mengenai konsep diri. Fitts (dalam Agustiani, 2006), mengemukakan bahwa konsep diri merupakan kerangka acuan (frame of reference) dalam berinteraksi dengan lingkungan. Agustiani (2006) menjelaskan bahwa konsep diri merupakan gambaran yang dimiliki seseorang mengenai dirinya, yang dibentuk melalui pengalaman-pengalaman yang dia peroleh dari interaksi dengan lingkungan. Penjelasan tersebut sejalan dengan pendapat Stuart dan Sundeen (dalam Keliat, 1992), bahwa konsep diri adalah semua ide, pikiran, kepercayaan dan pendirian yang diketahui individu tentang dirinya dan mempengaruhi individu dalam berhubungan dengan orang lain. Hal ini temasuk persepsi individu akan sifat dan kemampuannya, interaksi dengan orang lain dan lingkungan, nilai-nilai yang berkaitan dengan pengalaman dan objek, tujuan serta keinginannya. Dengan kata lain, konsep 
diri didefenisikan sebagai pandangan pribadi yang dimiliki seseorang tentang dirinya sendiri (Calhoun dan Acocella, 1995).

Hurlock (1999: 58) menyebutkan bahwa konsep diri adalah gambaran yang dimiliki orang tentang dirinya. Konsep diri ini merupakan gabungan dari keyakinan yang dimiliki orang tentang diri mereka sendiri - karakteristik fisik, psikologis, sosial, emosional, aspirasi, dan prestasi. Konsep diri menurut Minor dan Mowen (2002: 271) merupakan totalitas pikiran dan perasaan individu yang mereferensikan dirinya sendiri sebagai objek. Atwater (dalam Desmita ,2005: 180) menyebutkan bahwa konsep diri merupakan keseluruhan akan gambaran diri yang meliputi persepsi seseorang tentang diri dan perasaan keyakinan, dan nilai-nilai yang berhubungan dengan dirinya.

Konsep diri (Dariyo, 2004:80) merupakan gambaran diri tentang aspek fisiologis maupun aspek psikologis yang berpengaruh pada perilaku individu dalam penyesuaian diri dengan orang lainSejalan dengan defenisi tersebut Kobal dan Musek (2002) mendefenisikan konsep diri sebagai suatu kesatuan psikologis yang meliputi perasaanperasaan, evaluasi-evaluasi, dan sikap-sikap kita yang dapat mendeskripsikan diri kita. Demikian juga Paik dan Micheal (2002) menjelaskan konsep diri sebagai sekumpulan keyakinan-keyakinan yang kita miliki mengenai diri kita sendiri dan hubungannya dengan perilaku dalam situasi-situasi tertentu. Konsep diri juga dapat diartikan sebagai penilaian keseluruhan terhadap penampilan, perilaku, perasaan, sikap-sikap, kemampuan serta sumber daya yang dimiliki seseorang (Labenne dan Greene, 1969). Konsep diri sebagai suatu penilaian terhadap diri juga dijelaskan dalam defenisi konsep diri yang dikemukakan oleh Partosuwido, dkk (1985) yaitu bahwa konsep diri adalah cara bagaimana individu menilai diri sendiri, bagaimana penerimaannya terhadap diri sendiri sebagaimana yang dirasakan, diyakini, dan dilakukan, baik ditinjau dari segi fisik, moral, keluarga, personal, dan sosial.

Konsep diri adalah semua ide, pikiran, kepercayaan dan pendirian yang diketahui individu tentang dirinya dan mempengaruhi individu dalam berhubungan dengan orang lain (Potter \& Perry, 2009). Menurut Burns (1982) konsep diri adalah hubungan antara sikap dan keyakinan tentang diri sendiri, termasuk sikap, perasaan, persepsi, nilai-nilai dan perilaku yang unik dari individu tersebut. Santrock (2007) menggunakan istilah konsep diri yang mengacu pada evaluasi bidang tertentu dari individu sehingga muncul pula istilah konsep diri akademik.

Berdasarkan beberapa teori di atas dapat disimpulkan bahwa konsep diri adalah kumpulan keyakinan dan persepsi diri mengenai diri sendiri yang terorganisasi, dengan 
kata lain konsep diri tersebut bekerja sebagai skema dasar. Konsep diri memberikan sebuah kerangka berpikir yang menentukan bagaimana mengolah informasi tentang diri sendiri, termasuk motivasi, keadaan emosional, evaluasi diri, kemampuan dan banyak hal lainnya.

\section{Komponen Konsep Diri}

Calhoun dan Acocella (1995) menjelaskan bahwa konsep diri terdiri atas tiga dimensi yang meliputi:

a. Pengetahuan terhadap diri sendiri yaitu seperti usia, jenis kelamin, kebangsaan, suku pekerjaan dan lain-lain, yang kemudian menjadi daftar julukan yang menempatkan seseorang ke dalam kelompok sosial, kelompok umur, kelompok suku bangsa maupun kelompok-kelompok tertentu lainnya.

b. Pengharapan mengenai diri sendiri yaitu pandangan tentang kemungkinan yang diinginkan terjadi pada diri seseorang di masa depan. Pengharapan ini merupakan diri ideal

c. Penilaian tentang diri sendiri yaitu penilaian antara pengharapan mengenai diri seseorang dengan standar dirinya yang akan menghasilkan rasa harga diri yang dapat berarti seberapa besar seseorang menyukai dirinya sendiri.

Komponen yang membentuk konsep diri adalah citra tubuh, ideal diri, harga diri, identitas diri dan penampilan peran. Citra tubuh adalah sikap terhadap atribut fisik individu, karakteristik penampilan dan kinerja. Stuart \& Sundeen (dalam Ihsani, 2015) menyebutkan bahwa sikap ini mencakup persepsi dan perasaan tentang ukuran, bentuk, fungsi penampilan dan potensi tubuh saat ini dan masa lalu yang secara berkesinambungan dimodifikasi dengan pengalaman baru setiap individu.

Ideal diri adalah persepsi individu tentang bagaimana ia harus berperilaku berdasarkan standar, aspirasi, tujuan atau penilaian personal tertentu. Standar dapat berhubungan dengan tipe orang yang diinginkan atau sejumlah aspirasi, cita-cita, nilainilai yang ingin dicapai.

Harga diri adalah rasa seseorang mengenai dirinya. Rasa ini adalah suatu evaluasi dimana individu mempertahankan dirinya, merupakan penilaian pribadi terhadap hasil yang dicapai dengan menganalisis seberapa jauh perilaku memenuhi ideal diri. Frekuensi pencapaian tujuan akan menghasilkan harga diri yang rendah atau tinggi. Jika individu sering gagal maka cenderung harga diri rendah. Harga diri diperoleh dari diri sendiri dan orang lain. Aspek utama adalah dicintai dan menerima penghargaan dari orang lain (Stuart \& Sundeen dalam Ihsani, 2015) 
Identitas diri adalah sensasi individualitas dan keunikan yang disadari dan secara kontinu muncul sepanjang hidup yang merupakan bagian dari konsep diri. Identitas adalah pengorganisasian prinsip dari kepribadian yang bertanggungjawab terhadap kesatuan, kesinambungan, konsistensi dan keunikan individu.

Penampilan peran adalah sekumpulan harapan mengenai bagaimana individu menempati suati posisi tertentu dari perilaku. Peran adalah serangkaian pola perilaku yang diharapkan oleh lingkungan sosial berhubungan dengan fungsi individu di berbagai kelompok sosial. Peran yang ditetapkan adalah peran di mana seseorang tidak mempunyai pilihan. Peran yang diterima adalah peran yang terpilih atau dipilih oleh individu. Peran adalah sikap atau perilaku nilai serta tujuan yang diharapkan dari seseorang berdasarkan posisinya di masyarakat (Santrock, 2007).

Menurut Berk (dalam Dariyo, 2007) konsep diri ialah gambaran diri sendiri yang bersifat menyeluruh terhadap keberadaan diri seseorang. Konsep diri ini bersifat multiaspek yaitu meliputi 4 (empat) aspek seperti : (1). Aspek fisiologis, (2). Aspek psikologis, (3). Aspek Psikososiologis, (4). Aspek psiko-etika dan moral. Gambaran konsep diri berasal dari interaksi antara diri sendiri maupun antara diri dengan orang lain atau lingkungan sosialnya. Oleh karena itu konsep diri merupakan cara pandang seseorang mengenai diri sendiri untuk memahami keberadaan diri sendiri maupun memahami orang lain.

Berdasarkan teori-teori yang telah dikemukakan maka dapat ditarik simpulan bahwa komponen konsep diri terdiri dari komponen fisiologis, psikologis dan sosial.

\section{Pengambilan Keputusan Karier}

\section{Pengertian Pengambilan Keputusan karier}

Siswa kelas IX di sekolah menengah pertama (SMP), merupakan masa peralihan dimana siswa harus mengambil keputusan karir selanjutnya ketika sudah lulus dari SMP. Terry menyatakan bahwa pengambilan keputusan adalah pemilihan alternatif perilaku dari dua alternatif atau lebih. Pengambilan keputusan tersebut merupakan sebuah kegiatan untuk mendapatkan suatu kepuasan dalam hidup (Ibnu Syamsi, 2000: 5). Pengambilan keputusan dapat dianggap sebagai suatu hasil proses mental atau kognitif yang membawa pada pemilihan suatu jalur tindakan diantara beberapa alternatif yang tersedia. Setiap proses pengambilan keputusan selalu menghasilkan suatu pilihan akhir (Wikipedia, 2012).

Ibnu Syamsi (2000: 5) menyatakan bahwa pengambilan keputusan merupakan suatu kegiatan yang dilakukan dengan sengaja, tidak secara kebetulan, dan tidak boleh 
sembarangan. Kemampuan dalam pengambilan keputusan karir dapat diasah dalam setiap keputusan-keputusan kecil yang telah diambil sebelumnya, sehingga dapat memperkuat kemampuan pengambilan keputusan karir.

Berdasarkan beberapa penjelasan diatas maka dapat diperoleh kesimpulan bahwa pengambilan keputuan adalah proses pemilihan alternatif perilaku diantara beberapa alternatif yang tersedia yang menghasilkan sebuah keputusan akhir yang dilakukan dengan sengaja, tidak secara kebetulan dan tidak sembarangan.

Mengenai pengambilan keputusan karier, Dewa Ketut Sukardi (1993: 63) menyatakan bahwa pengambilan keputusan karir merupakan suatu proses dimana seseorang mengadakan suatu seleksi terhadap beberapa pilihan dalam rencana masa depan. Bagi siswa SMP, pilihan karir tersebut antara lain melanjutkan studi ke jenjang yang lebih tinggi, yaitu ke SMK atau ke SMA. Pilihan-pilihan tersebut harus diperimbangkan secara matang karena akan berpengaruh pada masa depannya nanti.

Munandir (1996: 191) menyatakan bahwa keputusan karir yang dimaksud adalah keputusan yang diambil secara arif dan penuh pertimbangan. Pengambilan keputusan seperti ini mutlak demi keberhasilan dalam hidupnya kelak dengan karir yang dipilihnya itu.

Berdasarkan beberapa pendapat ahli di atas dapat disimpulkan bahwa pengambilan keputusan karir adalah suatu proses seleksi terhadap alternatif-alternatif pilihan yang dilaksanakan secara sengaja dan serius serta penuh pertimbangan demi keberhasilan kehidupan karirnya dimasa yang akan datang.

\section{Aspek-Aspek Pengambilan Keputusan Karir}

Esensi dari sebuah pengambilan keputusan adalah proses penentuan pilihan (Sharf, 2016: 303). Secara alami, manusia akan diperhadapkan kepada berbagai pilihan dan secara alami juga ia dilatih mengambil keputusan dari pilihan-pilihan hidup yang dialaminya. Oleh karena itu sesungguhnya manusia akan terus menerus menentukan pilihan hidup dari waktu ke waktu sampai akhir kehidupan. Proses inilah yang disebut dengan pengambilan keputusan (Sharf, 2016: 303). Jadi, esensi dari sebuah pengambilan keputusan adalah proses penentuan pilhan. Hanya saja pada kenyataannya ada individu yang mampu dengan tepat mengambil keputusan ada juga yang tidak mampu.

Berdasarkan uraian mengenai teori Sharf di atas, maka dapat dikatakan bahwa pengambilan keputusan karir adalah proses penentuan pilihan karir. Mengantisipasi sebuah pilihan merupakan proses mengarahkan individu pada suatu pilihan yang tepat. David V. Tiedeman (Sharf, 2016: 304) mengemukakan bahwa keputusan untuk memilih 
pekerjaan, jabatan atau karir tertentu merupakan suatu rentetan akibat dari keputusankeputusan yang dibuat individu pada tahap-tahap kehidupannya di masa lalu.

Tiedeman dan O'Hara (Sharf, 2016: 307) membagi antisipasi dalam membuat keputusan karir menjadi empat proses, yaitu eksplorasi, kristalisasi, pemilihan, dan klarifikasi. Tiedeman menegaskan bahwa tahapan tersebut sebagai panduan (guideline) dalam mengantisipasi suatu keputusan.

a. Eksplorasi

Eksplorasi yang dimaksud adalah penjelajahan terhadap kemungkinan alternatif keputusan yang akan diambil. Melalui eksplorasi ini, individu mengetahui dengan jelas konsekuensi apa yang akan dialami jika mengambil keputusannya tersebut.

b. Kristalisasi

Tiedeman dan O'Hara (Sharf, 2016: 308) berasumsi bahwa kristalisasi merupakan sebuah stabilisasi dari representasi berpikir. Pada tahap ini, pemikiran dan perasaan mulai terpadu dan teratur. Keyakinan atas pilihan yang akan diambil menguat. Definisi tentang alternatif pilihan semakin jelas.

c. Pemilihan

Samahalnya dengan perkembangan kristalisasi, proses pemilihan pun terjadi. Masalah-masalah individu berorientasi kepada tujuan yang relevan, yaitu individu mulai mengorganisir dalam melengkapi dan menyesuaikan terhadap berbagai pilihan karir masa depan. Sehingga pada tahap ini individu percaya atas pilihannya.

d. Klarifikasi

Ketika seorang induvidu membuat keputusan lalu melakukannya, mungkin dalam perjalanannya ada yang lancer mungkin ada yang mempertanyakan kembali karena kebingungan. Pada saat individu mengalami kebingungan, seharusnya individu tersebut melakukan eksplorasi kembali, kristalisasi, lalu melakukan pemilihan alternatif kembali dan seterusnya.

Berdasarkan uraian di atas dapat kita ketahui bahwa ada empat proses dalam pengambilan keputusan karir, yaitu yakni eksplorasi, kristalisasi, pemilihan, klarifikasi. Keempat proses ini tidak selalu bersifat sekuensial, yaitu dapat terlompat, atau dilakukan hanya beberapa aspek. Hal yang ideal adalah saat pengambilan keputusan karir memenuhi keempat aspek tersebut dan bersifat sekuensial.

\section{Faktor-Faktor yang Mempengaruhi Pengambilan Keputusan Karir}

Ada banyak faktor yang mempengaruhi pengambilan keputusan k karir. Salah satu teori yang menjelaskan tentang faktor-faktor ini dikemukakan oleh Krumboltz 
dalam teori behavioral. Teori behavioral.

Krumboltz berasal dari teori belajar, yaitu teori belajar sosial oleh Bandura. Krumboltz menganggap bahwa ada dua faktor utama sebagai penentu dalam keputusan karir, yaitu faktor pribadi dan lingkungan. Lingkungan yang dimaksud adalah lingkungan kerja, syarat kerja, dan sebagainya. Kepribadian dan tingkah laku orang itu, lebih merupakan hasil belajar daripada pembawaan (Munandir, 1996: 115).

Ada empat faktor yang mempengaruhi pengambilan keputusan karir: yaitu faktor-faktor genetik, lingkungan, belajar, dan keterampilan menghadapi tugas atau masalah (Munandir, 1996: 97).

a. Faktor genetic

Faktor ini dibawa dari lahir berupa wujud dan keadaan fisik (wajah, jenis kelamin, ras, suku bangsa).

b. kondisi lingkungan

Faktor ini umumnya ada di luar kendali individu, tetapi pengaruhnya bisa direncanakan atau tidak bisa direncanakan.

c. Faktor belajar

Kegiatan ini hampir dilakukan setiap waktu sejak masa bayi. Pengalaman belajar ini mempengaruhi tingkah laku dan keputusan orang, antara lain tingkah laku pilihan pekerjaan.

d. Keterampilan menghadapi tugas atau masalah

Keterampilan ini dicapai sebagai sebuah interaksi atau pengalaman belajar, ciri genetik, bakat dan lingkungan.

Penjelasan lain mengenai faktor-faktor yang mempengaruhi pengambilan keputusan karir dikemukakan oleh Holland (Santrock, 2003:485) yaitu:

a. kelas Sosial

Pendidikan, secara alami, merupakan tangga untuk naik bagi remaja dari kalangan bawah. Hirarki sekolah dari tingkat menengah, akademi hingga universitas di program untuk mengarahkan siswa agar memasuki jenis karir tertentu.

b. Orang Tua dan Teman Sebaya

Sejak muda, anak-anak melihat dan mendengar tentang karir orang tuanya. Bahkan orang tua tertentu membawa anaknya ketempat kerjanya. Teman sebaya juga mempengaruhi perkembangan karir seorang remaja. Dalam suatu investigasi, remaja yang orang tua dan temannya mempunyai standar status karir yang lebih baik akan berusaha mencari status karir yang lebih tinggi juga, meskipun dia berasal 
dari kalangan berpenghasilan rendah.

c. Pengaruh Sekolah

Sekolah, Guru, dan Guru BK memberikan pengaruh yang sangat kuat dalam perkembangan karir bagi siswa. Sekolah adalah pijakan awal dimana seseorang pertama kali berkenalan dengan dunia kerja. Sekolah merupakan satu-satunya institusi di dalam masyarakat dewasa ini yang sanggup memberikan sistem yang diperlukan untuk pendidikan mengenai karir-instruksi, bimbingan, penempatan, dan koneksi sosial.

d. Gender

Banyak wanita lebih disosialisasikan dengan mengurus rumah dibandingkan dengan peran yang berhubungan dengan berkarir atau prestasi, mereka secara tradisional tidak merencanakan karir dengan serius, tidak mengeksplorasi pilihan karir secara mendalam, dan terpaku pada pilihan karir yang terstereotipe secara gender.

Menurut Holland (Santrock, 2003: 484), bahwa orang yang telah menemukan karir yang sesuai dengan kepribadiannya, ia akan lebih menikmati pekerjaan tersebut lebih lama daripada orang yang bekerja di bidang yang tidak sesuai dengan kepribadiannya. Hal ini memperkuat bahwa dalam pemilihan karir tidak dapat dilakukan dengan sembarangan. Pemilihan karir harus dilakukan dengan serius dan dengan pertimbangan yang matang.

Cara berpikir tradisional pada banyak wanita harus mulai dirubah. Pemilihan karir harus dilakukan dengan serius dan matang. Faktor gender bisa menjadi salah satu pertimbangan, tetapi bukan berarti tidak merencanakan karir karena mereka adalah wanita. Karena peran wanita nantinya sangat penting dalam keluarga, terutama bagi perkembangan anak-anaknya nanti, pertimbangan karir pada wanita harus dilakukan secara lebih matang tidak boleh asal-asalan.

Winkel dan M.M. Sri Hastuti (Winkel \& M.M. Sri Hastuti, 2004: 645-655) juga menjelaskan mengenai faktor-faktor yang mempengaruhi pengambilan keputusan karir, yang kemudian dapat dikelompokkan ke dalam dua faktor. Pertama, faktor internal, yaitu faktor yang berasal dari dalam diri individu sendiri. Kedua, faktor eksternal, yaitu faktor yang berasal dari luar diri individu. Kedua faktor tersebut diuraikan lebih lanjut sebagai berikut:

a. Faktor-Faktor Internal

Faktor-faktor internal adalah faktor yang berasal dari dalam diri individu sendiri, faktor itu antara lain: 
1) Nilai-nilai kehidupan yaitu ideal-ideal yang dikerjakan oleh seseorang, dimana dan kapan pun juga. Sekali terbentuk, nilai-nilai ini memegang peranan yang penting dalam keseluruhan perilaku seseorang dan mempengaruhi seluruh harapan serta lingkup aspirasi dalam hidup, termasuk bidang pekerjaan yang dipilih dan ditekuni.

2) Taraf intelegensi yaitu taraf kemampuan untuk mencapai prestasi- prestasi yang dalamnya berpikir memegang peranan penting.

3) Bakat khusus yaitu kemampuan yang menonjol di suatu bidang usaha kognitif, bidang keterampilan, atau bidang kesenian.

4) Minat yaitu kecenderungan yang agak menetap pada seseorang untuk merasa tertarik pada suatu bidang tertentu dan merasa senang berkecimpung dalam berbagai kegiatan yang berkaitan dengan bidang itu.

5) Sifat-sifat yaitu ciri-ciri kepribadian yang bersama-sama memberikan corak khas pada seseorang, seperti riang gembira, ramah, halus, teliti, terbuka, fleksibel, ceroboh, dan banyak lagi.

6) Pengetahuan yaitu informasi yang dimiliki tentang bidang-bidang pekerjaan tentang diri sendiri.

7) Keadaan jasmani yaitu ciri-ciri fisik dimiliki seseorang seperti tinggi badan, tampan dan tidak tampan, ketajaman penglihatan jenis kelamin.

b. Faktor-Faktor Eksternal

Faktor-faktor eksternal adalah faktor yang berasal dari luar diri individu antara lain:

1) Masyarakat yaitu lingkungan sosial-budaya dimana orang muda dibesarkan.

2) Keadaan sosial-ekonomi negara atau daerah yaitu laju pertumbuhan ekonomi yang lambat atau cepat sratifikasi masyarakat, diversifikasi masyarakat atas kelompok-kelompok yang terbuka atau tertutup bagi anggota dari anggota kelompok lain.

3) Status sosial-ekonomi keluarga yaitu tingkat pendidikan orang tua, tinggi rendahnya pendapatan orang tua, jabatan ayah atau ibu, daerah tempat tinggal dan suku bangsa.

4) Pengaruh dari seluruh anggota keluarga besar dan keluarga inti. Orang tua, saudara kandung dari orang tua, dan kakak menyatakan segala harapan mereka serta mengkomunikasikan pandangan dan sikap tertentu terhadap pendidikan dan pekerjaan.

5) Pendidikan pengaruh dari sekolah yaitu pandangan dan sikap yang 
dikomunikasikan kepada anak didik oleh staf petugas bimbingan tenaga pengajar mengenai nilai-nilai yang terkandung dalam bekerja, tinggi rendahnya status sosial, jabatan, dan kecocokan jabatan tertentu untuk anak laki-laki atau perempuan.

6) Pergaulan dengan teman sebaya yaitu beraneka ragam dan variasi harapan tentang masa depan yang terungkap dalam pergaulan sehari- hari.

Tuntutan yang melekat pada masing-masing jabatan dan pada setiap program studi atau latihan, yang mempersiapkan seseorang untuk diterima pada jabatan tertentu dan berhasil didalamnya Berdasarkan uraian mengenai faktor yang mempengaruhi pengambilan keputusan karir di atas, dapat disimpulkan bahwa perkembangan karir dipengaruhi oleh beberapa faktor ada yang berasal dari internal dan eksternal. Hal-hal yang mempengaruhi antara lain lingkungan, kondisi ekonomi, jenis kelamin, minat, dan banyak lagi. Semua hal tersebut akan mempengaruhi siswa dalam mengambil keputusan karir.

\section{Hipotesis}

Adapun hipotesis yang diajukan dalam penelitian ini adalah adanya hubungan antara konsep diri dengan pengambilan keputusan karier pada siswa SMP.

\section{Metode}

Metode yang dipakai untuk mengumpulkan data adalah dengan menggunakan skala Konsep Diri Akademik dan Skala Pengambilan Keputusan.

\section{Hasil}

\section{Uji Asumsi}

Sebelum melakukan analisis data dengan teknik Analisis Korelasi terlebih dahulu dilakukan uji asumsi normalitas sebaran untuk mengetahui normal tidaknya skor variabel Konsep Diri dan variabel Pengambilan keputusan Karier. Selain itu dilakukan uji asumsi untuk mengetahui linieritas hubungan antara Konsep Diri dengan pengambilan keputusan Karier. Uji asumsi dilakukan dengan menggunkan bantuan SPSS (Stastical Pakages For Social Science) versi 20.

\section{Uji normalitas}

Uji normalitas dilakukan terhadap 2 variabel penelitian, yaitu variabel Konsep diri dan penyesuaian diri dengan tujuan untuk mengetahui normal tidaknya skor masingmasing variabel penelitian. Hasil uji normalitas menunjukkan bahwa : 
a. Variabel konsep diri akademik berdistribusi tidak normal dengan nilai KolmogorovSmirnov Z 0,078 $\mathrm{p}=0,020$ maka $\mathrm{p}<0,05$

b. Variabel Pengambilan keputusan karier berdistribusi normal dengan nilai Kolmogorov-Smirnov Z 0,069 p = 0,069 maka p > 0,05

\section{Uji Linieritas}

Pengujian linieritas dilakukan terhadap variabel konsep diri akademik dan variabel pengambilan keputusan karier untuk mengetahui hubungan anatara konsep diri akademik dengan pengambilan keptusan karier. Hasil uji linieritas antara variabel konsep diri akademik dan variabel pengambilan keputusan karier menunjukkan bahwa Flinier sebesar 577,343 dengan $p=0,000(p<0,05)$ menyatakan ada hubungan linier antara variabel konsep diri akademik dengan variabel pengambilan keputusan karier.

\section{Uji Hipotesis}

Setelah dilakukan uji asumsi, selanjutnya dilakukan uji hipotesis dengan menggunakan teknik Analisis Korelasi product moment untuk menguji apakah ada hubungan anatara konsep diri akademik dengan pengambilan keputusan karier, dengan bantuan SPSS (Stastical Pakages For Social Science) versi 20.0. Berdasarkan hasil analisis data diketahui bahwa $=0,869$, dan $\mathrm{p}=0,000(\mathrm{p}<0,01)$ sehingga hipotesis dalam penelitian ini diterima.

\section{Pembahasan}

Berdasarkan analisis statistik dengan teknik Analisis Korelasi product moment diperoleh hasil $r_{x y}=0,869$ dan $\mathrm{p}=0,000(\mathrm{p}<0,01)$ yang menunjukkan bahwa ada hubungan antara konsep diri akademik dengan Pengambilan keputusan karier pada siswa SMP.

Proses perkembangan karir siswa Sekolah Menengah Pertama (SMP) mengalami perubahan dalam pemilihan karir karena beralih dari fase tentatif yang berada pada tahap transisi menuju fase realistik serta dengan adanya masalah-masalah yang berasal dari dalam diri, luar diri, dan keduanya. Kondisi sosial, ekonomi, budaya yang mengalami perubahan kearah perkembangan minat, sikap, harapan dan kemampuan berpengaruh dalam proses pengambilan keputusan karir yang merupakan bagian dari proses perkembangan karir dalam perencanaan hidup (life planning). Berdasarkan uraian tersebut, kematangan memilih karir meliputi: (1) pemahaman dan kemampuan membuat rencana yang tepat, (2) sikap konsisten terhadap tanggung jawab, dan (3) kesadaran terhadap segala faktor internal yang harus dipertimbangkan dalam membuat keputusan 
Philanthropy Journal of Psychology

Vol 5 Nomor 1 (2021), 157-174

ISSN 2580-6076 (Print), ISSN 2580-8532 (Online)

karir (Winkel, 1997: 575). Dari uraian di atas dapat kita lihat bahwa salah satu faktor yang dapat mempengaruhi keberhasilan proses perkembangan karir tersebut adalah tingkat kematangan pemahaman diri.

\section{Kesimpulan}

Hasil penelitian ini menunjukkan bahwa ada hubungan antara konsep diri akademik dengan pengambilan keputusan karier pada siswa SMP, sehingga hipotesis dalam penelitian ini dinyatakan diterima.

\section{Saran}

Adapun saran dari penelitian ini adalah

1. Bagi Siswa

Penelitian ini memberikan gambaran bahwa siswa perlu mempertimbangkan hasil keputusan terkait karier kedepan dan perlunya Kemandirian siswa dalam menentukan jenjang karier lanjutan

2. Bagi Guru Pendamping

Hasil Penelitian ini dapat memberikan masukan bagi guru pembimbing dalam membuat strategi untuk memperkenalkan karier kedepan yang dapat dipilih oleh Siswa terutama kelas IX

3. Bagi Sekolah

Pihak sekolah memberikan fasilitas bagi siswa untuk dapat mengenal jenjang karier lanjutan

4. Bagi Orangtua

Orang tua diharapkan mampu memberikan dukungan kepada anak supaya memilih karier kedepannya.

\section{Referensi}

Agustiani, H, (2006), Psikologi Perkembangan Pendekatan Ekologi kaitannya dengan Konsep Diri, Bandung: Pt. Refika Aditama

Callhoun, JF. Acocella, JR., (1995), Psychology of Adjustment and Human Relationship. (Alih bahasa: AS Satmoko), Semarang: IKIP Semarang Press

Crites J.0. (2007). Vocational Psychology: The Study of Vocational And Development, New York: Mc Grow Hill.

Dariyo, A., (2004). Psikologi Perkembangan Remaja, Bogor: Ghalia Indonesia

Desmita, (2005), Psikologi Perkembangan, Bandung: PT. Remaja Rosdakarya 
Philanthropy Journal of Psychology

Vol 5 Nomor 1 (2021), 157-174

ISSN 2580-6076 (Print), ISSN 2580-8532 (Online)

Gerungan, WA, (2004), Psikologi Sosial, Bandung: PT. Refika Aditama

Hurlock, B, (2001), Perkembangan Anak Jilid 2, Jakarta: Erlangga

Marsella, AJ, (2006), Indigenous \& Cultural Psychology, NewYork: Springer

Minor,M \& Mowen, J, (2002), Perilaku Konsumen, Jakarta: Erlangga

Munandir. (1996). Program Bimbingan Karier Di Sekolah, Jakarta: Jalan Pintu Satu.

Potter, PA, \& Perry, AG, (2009), Fundamental Of Nursing , 7th ed, St. Louis: Mosby Elsevier

Santrock, J. (2003). Adolescence Perkembangan Remaja, Jakarta: Erlangga.

Santrock, JW, (2007), Remaja, Jilid 1 (Alih bahasa Benedictine Widyasinta), Jakarta; Erlangga

Salomone, P.R., \& Mangicaro, L.L. (1991). Difficult cases in carier counseling: IV---Floundering occupational moratorium, The Career Development Quarterly.

Sharf. (2016). Applying Career Development Theory of Counseling, California: Wadswort,inc.

Syamsi, Ibnu. (2000). Pengambilan Keputusan dan Sistem Informasi, Jakarta: Sinar Grafika Offset.

Sukardi, D.K. (1993). Psikologi Pemilihan Karier, Jakarta: Rineka Cipta.

Utoyo, Imam (1989). Bimbingan Dan Konseling Karir, Malang: PBB FIP UM.

W.S Winkel (1997). Bimbingan dan Konseling di Institut Pendidikan, Jakarta : Grasindo 